\title{
Atualidades do trabalho
}

$\mathrm{O}$

NÚMERO 98 de ESTUDOS AVANÇADOS mantém seu propósito de uma publicação acadêmica pluralista, voltada para a disseminação de conhecimento produzido em todos os campos científicos e para a divulgação de ensaios sobre os mais distintos aspectos da cultura. ${ }^{1}$

De início, o volume contém substantivo número de estudos baseados em sólidas investigações empíricas que abordam o mundo contemporâneo do trabalho. Um primeiro grupo de estudos explora as relações entre trabalho, gênero e cuidado. Não são poucos os aspectos examinados: os diferentes significados do "cuidado"; as relações entre cuidado, responsabilidade e compromisso; o cuidado sob enfoque jurídico e sindical. Nesse conjunto, destaca-se estudo comparativo que aponta diferenças e similitudes entre experiências e organizações sociais do cuidado no Brasil, na França e no Japão.

Embora sob outra perspectiva teórico-metodológica, porém ainda no interior do mesmo campo temático, outro conjunto de estudos tem por objeto as novas metodologias do trabalho contemporâneo. Questões relevantes dizem respeito à patogênese provocada por essas novas metodologias à vida e à saúde dos trabalhadores; a precarização das condições de trabalho mediante a flexibilização das relações contratuais entre trabalhadores e empregadores cujo exemplo marcante é a chamada uberização na era do trabalhador justin-time. $\mathrm{O}$ conjunto igualmente coloca em discussão o retorno à arena política brasileira dos projetos de reforma sindical.

Na mesma linha de preocupações para com os problemas de nossa contemporaneidade situam-se os estudos no domínio das conexões entre meio ambiente e desenvolvimento. Trata-se de uma campo vasto e complexo. Neste número 98 comparecem duas sugestivas contribuições. A primeira caracteriza de forma minudente a bioeconomia, fortemente relacionada às potencialidades dos recursos naturais no estado do Amazonas. A segunda se ocupa de tema da maior relevância não apenas para a economia e sociedade neste país, mas também para o mundo globalizado. Trata-se do balanço do estado da arte em torno da dinâmica climática e biogeográfica do Brasil no Último Máximo Glacial (UMG).

Este número contém ainda copiosos e substantivos estudos culturais. É muito difícil dirigir o olhar do leitor quando todas as contribuições, inclusive as resenhas bibliográficas, revelam a riqueza da diversidade dos temas abordados. Esse conjunto retoma clássicas, porém sob nova leitura, preocupações com as relações entre memória e esquecimento; o teatro tardio de Samuel Beckett a partir do conceito de paródia; os mecanismos políticodiscursivos que caracterizam a epistemologia dos padres da Companhia de Jesus na obra $O$ Jesuita de José Alencar; as disputas estéticas e ideológicas no pensamento católico brasileiro por meio de artigo de autoria de Murilo Mendes; a reflexão sobre a vida e a obra do Marquês de Sade a partir de distintas noções de arquivo; a possibilidade da existência de indivíduos em Mayombe, de Pepetela; os trajes e hábitos (não)vestimentares dos indígenas brasileiros tratados a partir de iniciativa de Johan Maurits van Nassau-Siegen em festa ocorrida em Haia, em 1644. Esse bloco ainda acolhe interessantes ensaios sobre a obra de José Saramago, em especial História do cerco de Lisboa.

Nota

1 Para mais informações, consultar Bosi (2011).

Referência

BOSI, A. A revista Estudos Avançados. Estudos Avançados, v.25, n.73, p.155-58, 2011. Disponível em: <http://www.scielo.br/scielo.php?script=sci_arttext\&pid=S0103-40142011000300019\&lng $=\mathrm{pt} \& n r m=\mathrm{iso} \& \mathrm{t} \operatorname{lng}=\mathrm{pt}>$.

Sergio Adorno ${ }^{\mathrm{I}}$

I Faculdade de Filosofia, Letras e Ciências Humanas, Universidade de São Paulo, São Paulo, Brasil. @-sadorno@usp.br / https://orcid.org/0000-0002-5358-1289 